\title{
Demandas de poder no Conselho Pedagógico - reflexões a partir de um estudo de caso num agrupamento de escolas
}

\author{
Daniela Vilaverde e Silva \\ Universidade do Minho, Portugal
}

\begin{abstract}
Resumo
O presente artigo centra-se num estudo sobre os diferentes jogos de poder e interesses mobilizados pelos actores escolares num dos órgãos de administração das escolas básicas públicas: o Conselho Pedagógico. A implementação do regime de administração das Escolas impulsionado pelo Decreto-Lei no 115-A/98 trouxe alterações à composição do Conselho Pedagógico. Assim, a pluralidade de actores, decorrente quer da sua composição legal quer da formação dos Agrupamentos de Escolas, veio atribuir uma maior complexidade a este órgão. A partir de um estudo de caso num Agrupamento de Escolas pretendemos, por um lado, analisar diferentes poderes entre os membros do Conselho Pedagógico e, por outro, reflectir sobre a forma como os docentes percepcionam a participação dos diferentes actores que compõem este Conselho. Os dados obtidos na investigação denunciam a existência de diferentes relações de poder e interesses entre os membros deste Conselho. As decisões, os procedimentos e as práticas a adoptar no Agrupamento espelham sobretudo uma maior predominância dos interesses dos docentes do $2^{\circ}$ e $3^{\circ}$ ciclos face aos educadores de infância e docentes do $1^{\circ}$ ciclo, desenvolvendo-se, desta forma, interesses de ciclos que podem fragilizar dinâmicas conotadas com a lógica democrática.
\end{abstract}

Palavras-chave

Conselho Pedagógico; Poderes; Interesses

\section{Introdução}

A conceptualização da Escola como organização suscita, na actualidade, novas reflexões e interrogações decorrentes, sobretudo, das 
alterações legais proporcionadas pelo Decreto-Lei n.. $115-\mathrm{A} / 98$, pelo DecretoRegulamentar n.. 12/2000 e posteriormente pelo Despacho Conjunto n.. 13 $313 / 2003$, de 8 de Julho que definem e regulamentam a constituição dos Agrupamentos de Escolas. A unidade organizacional 'Escola' foi sendo substituída pela 'unidade' Agrupamento de Escolas. Neste novo contexto, analisar a organização Agrupamento de Escolas significa estudar um conjunto de organizações escolares cuja 'direcção' e gestão se encontram centralizadas nos órgãos de administração da Escola-sede. Esta nova orgânica leva-nos a colocar a hipótese de que nos encontramos em presença de mais um processo de (re)centralização do sistema de ensino, no sentido em que a formação dos Agrupamentos verticais vem impôr uma nova forma de homogeneização de práticas, mas, agora, em torno da unidade organizacional Agrupamento.

À luz desta contextualização, urge convocar o campo teórico da sociologia das organizações para a compreensão desta nova "organização Escolar". Para tal, seleccionamos o modelo político de análise das organizações, o qual parece constituir uma opção fundamental para o estudo e reflexão das dinâmicas de poder que são mobilizadas pelos actores Escolares. Assim sendo, o estudo dos órgãos de topo dos Agrupamentos de Escolas emerge como um exercício de compreensão das relações de poderes estabelecidas entre os diferentes membros dos diferentes órgãos: Assembleia do Agrupamento, Conselho Pedagógico, Conselho Executivo e Conselho Administrativo, pelo que a análise interna dos órgãos dos Agrupamentos de Escolas constitui um objecto premente de investigação. Seguidamente, debruçar-nos-emos sobre algumas dimensões de análise do funcionamento de um dos órgãos de gestão: o Conselho Pedagógico, a partir de uma investigação realizada no Agrupamento de Escolas Alfa, tendo em conta essencialmente o ponto de vista dos seus elementos docentes. A metodologia utilizada incluiu a realização de um inquérito por questionário aos docentes, a realização de entrevistas aos membros docentes do Agrupamento e a observação das reuniões do Conselho Pedagógico durante o ano lectivo 2002/20031.

Este artigo divide-se em duas partes. Na primeira, exploramos teoricamente alguns dos pressupostos do modelo político da sociologia das organizações, no qual enfatizamos o fenómeno do poder. Na segunda, 
procuramos desocultar alguns jogos de poder que são mobilizados pelos actores Escolares, nomeadamente, pelos docentes do Conselho Pedagógico em estudo.

\section{O Modelo político de análise}

O modelo político concebe as organizações como "sistemas de actividade política" (Morgan, 1996:152), onde os valores e a diversidade de interesses fervilham no quotidiano da actividade das organizações, dando origem, por vezes, a conflitos e à concepção de jogos de poder. Estes jogos de poder encontram-se escondidos no interior das organizações, sendo, por vezes, ocultados pelos actores que procuram mascarar e dissimular os seus interesses, estratégias e até conflitos. Neste contexto, "a noção de política nasce da ideia de que, quando os interesses são divergentes, a sociedade deverá oferecer meios de permitir aos indivíduos reconciliarem as suas diferenças através da consulta e da negociação" (idem: 146).

A análise da actividade política não é transparente, encontrando-se mergulhada nos meandros da estrutura informal da organização ou, nas palavras de Lima (1992: 161), na "cripto-estrutura" organizacional. Decorrente da ruptura com a visão unitária da organização, este modelo centraliza o papel político dos actores organizacionais na configuração da estrutura informal organizacional. Nesta linha, Bolman \& Deal (1989:109) referem que

numa perspectiva estruturalista, as organizações são concebidas como sistemas racionais. A questão central é saber como se desenha uma estrutura que seja apropriada para a persecução das propostas organizacionais. Os recursos humanos também vêem as organizações como intencionadas para serem racionais mas enfatizam o mau funcionamento que ocorre por uma má articulação entre as necessidades da organização e as necessidades individuais.

Neste sentido, o "debate", o "mau funcionamento" e as "lutas" políticas protagonizadas pelos actores organizacionais desenham uma outra estrutura paralela à estrutura formal: a estrutura informal. É na estrutura informal que vários autores filiam o modelo político. Como exemplo apresentamos Bolman \& Deal (1989:109) quando referem que "os objectivos organizacionais e as decisões emergem de atitudes/processos de regateio, negociação e intriga de posições entre indivíduos e grupos". Assim sendo, a organização na 
perspectiva política é constituída por "ligações de indivíduos e grupos" (Idem, Ibidem), que condicionam o funcionamento organizacional. Também Sá (1997: 145) considera que "como os objectivos e a decisão organizacional, a estrutura é também produto do processo de lutas e negociações permanentes entre indivíduos e grupos portadores de projectos particulares, sujeita, por isso, a remodelações frequentes consoante a correlação de forças em vigor".

Nos estudos desenvolvidos por Baldridge, em Universidades dos Estados Unidos da América, o autor concluiu que o modelo político é o modelo mais adequado para "captar a realidade da educação superior" (citado por Bush, 1995: 74). Como afirma Baldridge (citado por Bush, 1995: 74):

Quando olhamos para o processo complexo e dinâmico que emergiu nas Escolas modernas, não vemos os aspectos rígidos e formais burocráticos nem o calmo consenso dos elementos de um colégio académico. Pelo contrário, [...] [grupos de interesses] emergem. Estes grupos articulam os seus interesses de diferentes maneiras, fazendo pressão para que o processo de decisão se direccione num determinado ângulo [...] poder e influência, uma vez articulados, atravessam um processo complexo.

Seguindo esta perspectiva, a dinâmica complexa do quotidiano das organizações adquire um novo significado teórico, alicerçado em novos conceitos que redimensionam os jogos de poder e de influência mobilizados pelos diferentes actores organizacionais.

\subsection{A Organização Escolar como organização micropolítica}

A aplicação do modelo político à organização Escolar constitui uma das dimensões complementares para a compreensão e desmontagem das práticas dos actores organizacionais no que converge, sobretudo, às dimensões mais micro-analíticas.

Seguindo a linha de Bush (1995), o modelo político apresenta algumas características que explicamos de seguida.

$\mathrm{O}(\mathrm{s})$ grupo(s) de interesse são o objecto por excelência de análise de investigação deste modelo. As interacções entre os grupos em actividade constituem o cerne do presente modelo.

Por força da análise destas interacções, os interesses individuais e grupais desvendam-se o que pode originar conflitos no seio das organizações devido à diversidade de interesses e ideologias contraditórias dos actores 
organizacionais. Nesta óptica, também as metas e objectivos da organização são instáveis, ambíguas e contestáveis, podendo "as metas ser disputadas e depois tornarem-se elementos significativos no conflito entre grupos" (idem, 74). As decisões, muitas vezes, são definidas por processos de negociação: "nas arenas políticas as decisões emergem depois de um processo complexo de regateio e negociação" (idem, ibidem) emergentes após a clarificação dos diferentes jogos de poder organizacionais.

Nesta perspectiva, a racionalidade presente já não é uma racionalidade absoluta mas antes uma "racionalidade política" (Lima, 1992: 59) comandada pelas diferentes lógicas de acção que os actores organizacionais mobilizam no contexto organizacional.

O modelo político no seio das organizações escolares pode evocar a ênfase num plano mais micropolítico. Esta leitura é subsidiária de alguns autores, como González (1993), Costa (1996), que consideram que o modelo político pode assumir duas formas de focalização: macro e micro. Assim, seguindo a linha de pensamento de González (1993: 183), a Escola pode ser objecto de estudo a partir da perspectiva macro política quando analisa sobretudo "o papel políicico e ideológico que a escola desempenha no contexto sócio-político e cultural mais amplo de que faz parte". Por outro lado, numa perspectiva micropolítica, a análise centra-se na procura da compreensão das dinâmicas dos actores organizacionais ${ }^{2}$, uma vez que esta perspectiva sociológica chama a atenção para a constituição de grupos de interesse, conflitos, coligações e estratégias que os diversos actores organizacionais recorrem para alcançarem a concretização dos seus objectivos/interesses no seio das organizações. Assim sendo, "mais importante que a resolução dos conflitos, a marca do modelo político, no dizer de Bolman \& Deal (1984: 119), recai primacialmente nas estratégias e táticas do conflito" (Estêvão, 1998: 185).

O interesse e o desenvolvimento da perspectiva micropolítica no estudo das organizações escolares remontam, segundo Blase (1991: 7), à década de 70, sendo lannaccone (1970, cit. por Blase, 1991) a introduzir o conceito de micropolítica na sociologia organizacional, quando aplicou este modelo ao estudo das organizações escolares públicas ${ }^{3}$. A partir deste marco foram vários os autores que se debruçaram no estudo desta perspectiva, procurando a sua transposição para a análise do contexto educativo. Nesta 
acepção destacamos alguns autores como Ball (1994), Blase (1991) e Hoyle (1988), que contribuíram para o avanço dos estudos da organização Escolar, focalizando o quotidiano da vida escolar.

O estudo das dinâmicas organizacionais constitui uma forma mais completa de investigar a realidade organizacional. Como afirma Anderson \& Blase (1994: 99)

Tradicionalmente, o estudo da política educativa versava sobre o conflito de interesses pessoais, compromissos ideológicos e recursos materiais. Os estudos sobre estes conflitos tendiam a concentrar-se na legislação estatal e federal, nas juntas Escolares, nos sindicatos, nos grupos de interesses especiais e nos administradores. Mas recentemente, no âmbito educativo, voltou-se a atenção para as políticas organizacionais ou micropolíticas [que se] referem às negociações menos visíveis nos bastidores do poder.

Na mesma perspectiva, Hoyle (1988: 250) refere-se ao estudo da micropolítica como um "under-world" organizacional, na qual se desenrolam as "máfias organizacionais", as "agendas ocultas", os "jogos políticos" que constituem "o lado obscuro da vida organizacional" das Escolas. Assim, a micropolítica centraliza essencialmente o universo oculto e os jogos entre as estruturas formais e informais das organizações.

Segundo o pensamento de Blase (1991: 11), a micropolítica concentrase no

uso formal e informal do poder por indivíduos ou grupos para alcançar as suas metas nas organizações. Na maior parte, as acções políticas resultam das diferenças percebidas entre os indivíduos e os grupos, juntamente com a motivação do uso do poder para influenciar e/ou para proteger. Apesar de que as ditas acções motivam conscientemente qualquer acção, consciente ou inconsciente, podem ter um sentido político numa dada situação. Tanto a cooperação como as acções conflituais são parte do domínio das micropolíticas. Assim, os factores macro e micropolíticos interactuam frequentemente.

Nesta acepção, a perspectiva micropolítica torna-se imprescindível para uma melhor compreensão das dinâmicas, das lógicas de acção dos actores que se desenvolvem na organização escolar, uma vez que esta pode ser concebida como "uma entidade política, quer dizer, como um sistema construído por indivíduos e grupos em interacção, que perseguem interesses diferentes [...] defendem distintas ideologias através do uso do poder e de outros recursos" (González González, 1994: 50-51). 
A perspectiva micropolítica reivindica a clarificação de um conjunto de conceitos-chave, nomeadamente, o conceito de poder, conflito, e interesse(s). A compreensão destes conceitos entronca na necessidade de procurarmos desocultar também os pressupostos estruturantes do modelo político. No entanto, neste artigo apenas focaremos o conceito de poder, conforme apresentamos seguidamente.

\subsection{O Poder}

O conceito de poder incorpora uma multiplicidade de definições complexas. Sendo um dos mais importantes fenómenos sociais deste modelo, importa, neste ponto, debruçarmo-nos sobre algumas especificidades conceptuais e processuais do exercício do poder nas organizações em geral e nas organizações escolares em particular. Neste sentido, concordamos com Crozier (1963: 176) quando afirma que o estudo do poder no âmbito da sociologia das organizações constitui "um problema difícil [já que] as relações humanas que se estabelecem na ocasião dos fenómenos de poder não têm como efeito a simplicidade e a previsibilidade dos esquemas behavioristas do tipo estímulos".

De acordo com as diferentes perspectivas teóricas da sociologia organizacional, o poder é identificado de diferentes modos. Nas teorias clássicas da administração, protagonizadas nomeadamente por Taylor e Fayol, que dominaram sobretudo nos anos vinte, o poder (de influência) é praticamente secundarizado. Referindo-se a estes teóricos, Crozier (1963:177) considera que "a teoria racionalista clássica da organização científica pretende de facto ignorar completamente o problema" da complexidade do poder nas organizações.

É com Weber que o poder ganha consistência no seio da sociologia organizacional. Intimamente ligado aos conceitos de autoridade e dominação, o poder conquista a forma mais pura na ordem legal, definido como "toda a probabilidade de impor a própria vontade numa relação social" (Weber, 1991: 33). Contudo, a relação de poder entre os diferentes actores circunscreve-se à relação superior-subordinado, reduzindo o sistema de relações sociais ao uso da autoridade, assente em formas legais, negando e até ignorando o campo da autonomia relativa dos actores organizacionais. Neste sentido, 
Crozier (1963: 177) critica "o modelo mecanicista do comportamento humano sobre o qual a teoria [burocrática] repousa, [uma vez que] exclui as relações complexas e ambíguas que se desenvolvem à volta das relações do poder".

Assim, atendendo exclusivamente à dimensão legal-formal, o modelo burocrático weberiano carece de complementaridade para uma análise sociológica mais completa das organizações, pois

uma sociologia das organizações não poderá quedar-se pelo estudo apenas da morfologia organizacional, das estruturas formais de poder, terá de considerar também a estrutura informal, aquela [...] que não se encontra descrita nos estatutos e raramente aparece nos jornais; em suma, a 'rede informal das organizações' (Lima, 1992: 77).

É nesta estrutura informal que o conceito de poder se afirma e desenvolve à "margem da lei", tendo em conta o "reconhecimento de que a autoridade formal é apenas uma das fontes de poder" (Estêvão, 1998: 184).

A ruptura com uma concepção unilateral de poder leva-nos a considerar, de acordo com os contributos de Hoyle (1988: 258), a distinção entre duas dimensões de poder: o poder de autoridade, "suportado legalmente" (que na linha weberiana corresponde ao poder legal-formal) e o poder de influência, que se refere "à capacidade de afectar as acções dos outros, sem qualquer sanção legal" (Hoyle, 1988: 258).

$\mathrm{Na}$ 'nova' conceptualização de poder, este assume-se como um conceito multifacetado, negando a exclusividade do poder formal, inserindose nas dimensões informais, nos "sistemas de acção concretos", onde o(s) poder(es) se encontra $(m)$ presente(s) numa pluralidade de actores. Nesta perspectiva, o modelo político assenta na omnipresença ${ }^{4}$ do poder nos diferentes actores, uma vez que

nenhum actor 'armazena' o poder, mesmo que exista nas estruturas. Exerce-o, sacando os recursos sempre assimétricos que as estruturas de um contexto de acção põem à sua disposição, é ao exercê-lo que lhe dá a sua realidade e a sua eficácia, e é só assim que traduz essa assimetria de recursos em acção social (Friedberg, 1995: 116) ${ }^{5}$.

Crozier \& Friedberg (1977) distinguem quatro fontes de poder6 que decorrem de quatro fontes de incerteza:

a) as que derivam de uma competência particular ou especialização funcional de um determinado membro da organização, o qual é 
dificilmente substituível em virtude de possuir um saber-fazer, conhecimento, a experiência do contexto que permite resolver determinados problemas da organização. O especialista encontrase numa posição mais favorável nas negociações que os restantes actores organizacionais;

b) as que decorrem da relação entre organização e ambiente. Esta segunda fonte aproxima-se da primeira no sentido em que se torna necessária a existência de um especialista de controlo das demandas ambientais. Segundo os autores, a organização depende desse controlo a dois níveis. Por um lado, para obter os recursos materiais e humanos necessários ao desenvolvimento organizacional e, por outro, para 'vender' o seu produto, quer se trate de um bem material ou imaterial;

c) as que são originárias das fontes de comunicação e dos fluxos de informação entre as unidades e os membros organizacionais. A forma como estas se encontram organizadas influencia as questões do poder, no sentido em que a posse de determinada informação oferece maior poder ao actor. Os autores advertem ainda para o processo decisório do director da organização, uma vez que este necessita, muitas vezes, de informações fornecidas pelos seus subordinados acerca de determinadas situações de trabalho. Neste exemplo concreto, os subordinados dispõem de poder sobre o director no sentido em que podem influenciar o conteúdo das decisões, manipulando-as de acordo com os seus próprios interesses;

d) as que ocorrem da existência de regras organizacionais. Apesar de as regras organizacionais terem como destino suprimir as fontes de incerteza, elas podem paradoxalmente originar outras fontes de incerteza, podendo, numa versão mais radical, contradizerem-se umas às outras. Se partirmos do principio que as regras constituem "um meio nas mãos do superior para obter um comportamento conforme da parte dos seus subordinados" (cf. Crozier \& Friedberg, 1977), caímos na tentação de construir uma imagem redutora do exercício das regras organizacionais. O poder exerce-se num duplo sentido: por um lado, o superior socorre-se das regras e, por outro, 
as regras protegem os subordinados de certas arbitrariedades cometidas por parte do superior.

Podemos assim reflectir sobre a indissociabilidade do conceito de poder nesta perspectiva sociológica com o conceito de "zonas de incerteza", no sentido em que

os actores organizacionais utilizam as zonas de incerteza à sua disposição para negociar [...] e para impôr, dentro da medida da possibilidade, as suas próprias orientações aos outros actores, descobre-se uma segunda estrutura de poder paralela aquela que codifica e legitima o organograma oficial [...] completando, corrigindo, anulando as prescrições formais. Esta estrutura de poder constitui, de facto, o verdadeiro organograma da organização (Crozier \& Friedberg, 1977: 90).

Se adoptarmos a perspectiva da análise estratégica, na qual o actor constitui o ponto de partida de qualquer investigação, então a conceptualização do poder enquanto "fundamento das relações" entre os actores deve necessariamente atender à dimensão relacional em que estes se encontram. Seguindo os contributos de Crozier \& Friedberg (1977: 65), o exercício do poder "implica sempre a possibilidade de agir para determinados indivíduos ou grupos sobre outros indivíduos e grupos" e neste sentido o poder é "uma relação e não um atributo dos actores" que requer a existência de uma negociação7 (itálico dos autores).

Neste jogo de poder entre os indivíduos ou grupos organizacionais podem-se estabelecer três formas de relações sociais de poder. Por um lado, as relações entre os actores são relações instrumentais no sentido em que se estudam as diferentes formas de "dominação e de controlo social que interiorizadas pelos diferentes actores - dão origem ao fenómeno bem conhecido de 'ajustamento por antecipação' e que não necessita de uma ligação consciente da parte de um actor para outro" (Crozier \& Friedberg (1977: 67) e, neste caso, as acções dos indivíduos arrastam "um conjunto de consequências imprevisíveis e 'disfuncionais'" (Crozier \& Friedberg, 1977: 67).

Por outro lado, as relações entre os actores são intransitivas ${ }^{8}$, uma vez que partem do pressuposto de que o poder é "inseparável dos actores implicados numa relação [então] cada acção constitui um jogo específico à volta do qual se cria uma relação de poder particular" (Crozier \& Friedberg, 1977: 68). Estes autores caracterizam também as relações de poder como 
relações recíprocas mas desequilibradas. A reciprocidade advém, essencialmente, das negociações das relações entre os actores, pois "se uma das partes em presença não tem nenhum recurso a ligar uma relação, ela não tem nada a mudar: ela não pode entrar numa relação de poder" (idem, ibidem $)^{9}$. Se o envolvimento das partes é essencial, também é imprescindível que exista um desequilíbrio dos recursos entre os actores para que se possa afirmar que um determinado actor "se encontra em relação de poder diante da outra" (idem, ibidem), sendo esta relação favorável para uma delas. Contudo, Crozier \& Friedberg (1977: 65) advertem para o facto de este desequilíbrio ser confundido com a anulação do outro actor ou à redução deste à condição de objecto. Neste sentido, os autores afirmam que, apesar de as relações de poder se constituírem como "relações de força [...] um não é totalmente diminuído face ao outro" (1997: 69).

A existência de relações de poder mobiliza os recursos e as forças de cada actor, determinando as "possibilidades de acção" da posição dos mais desfavorecidos. Segundo esta perspectiva, a obtenção de um comportamento de um actor depende da "sua própria capacidade de acção", sendo esta imprevisível para a parte dominante. Neste sentido, importa sublinhar que

o poder reside pois na margem de liberdade que dispõe uma das partes numa relação de poder dentro da possibilidade mais ou menos grande de recusar o que a outra lhe pede. E a força, a riqueza, o prestígio, a autoridade, os recursos que uns possuem não intervêm senão na medida em que fornecem uma maior liberdade de acção (Idem: 69-70, itálico dos autores).

O estudo do poder no campo organizacional ${ }^{10}$, apesar de neste ponto apenas termos aflorado algumas dimensões teóricas deste fenómeno no contexto organizacional, é indispensável no ofício da investigação organizacional ${ }^{11}$, nomeadamente no que concerne à desmontagem analítica da estrutura de poder estabelecida no plano formal que posteriormente se cruza com os jogos de poder inscritos nos "sistemas de acção concretos" (Crozier \& Friedberg, 1977) da organização. Também Berger (2000: 43) segue a mesma linha quando afirma que

o sociólogo desejará conhecer acima de tudo a 'estrutura informal de poder' (como foi chamada por Floyd Hunter, sociólogo americano interessado por estes assuntos), que constitui uma configuração de homens e poder que não se encontra descrita nos estatutos [...] Isto não significa necessariamente que ele encare os mecanismos oficiais como totalmente ineficientes ou sua definição legal como totalmente ilusória. 
Nesta perspectiva, o estudo das relações de poder constitui uma agenda fundamental no estudo das organizações, já que o seu estudo "dá conta das 'multirracionalidades' no interior da organização" (Estêvão, 1998: 188).

\section{O Conselho Pedagógico: algumas considerações formais}

O Conselho Pedagógico é o "órgão de coordenação e orientação educativa do Agrupamento, nomeadamente nos domínios Pedagógicodidáctico, da orientação e acompanhamento dos alunos e da formação inicial e contínua do pessoal docente e não docente" (Artigo 24ํ do Decreto-Lei no 115-A/98 e Regulamento Interno do Agrupamento Alfa).

Actualmente, o Conselho Pedagógico reveste-se de uma pluralidade

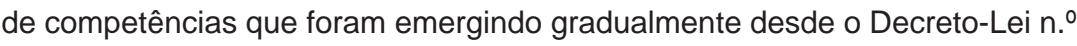
735-A/74, de 21 de Dezembro e do Decreto-Lei n. 769-A/76, de 23 de

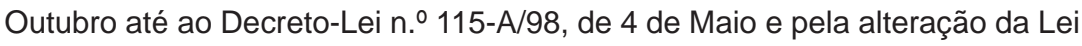
n. $.24 / 99$, conforme verificamos no quadro 1 . 


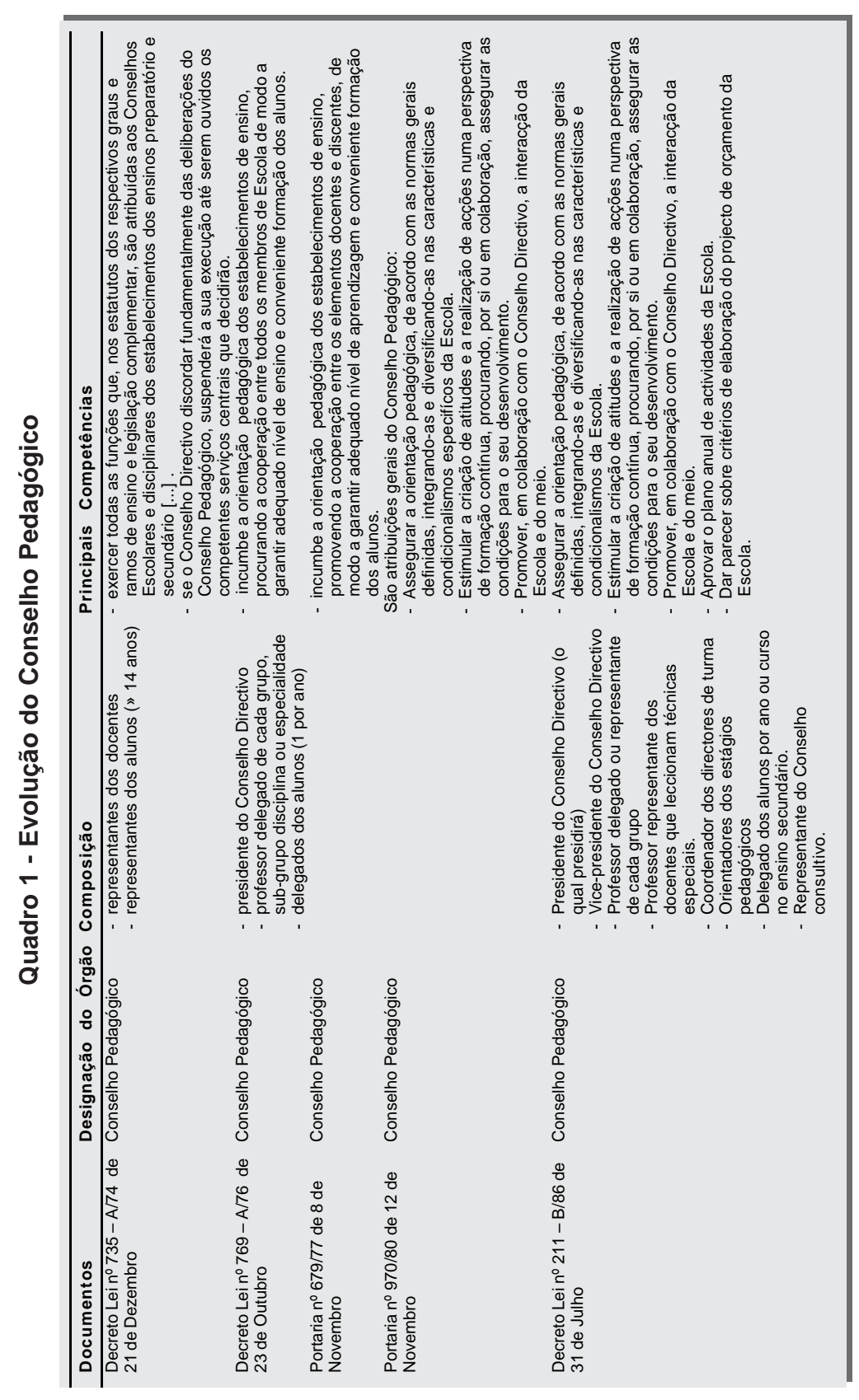


46 Daniela Vilaverde e Silva

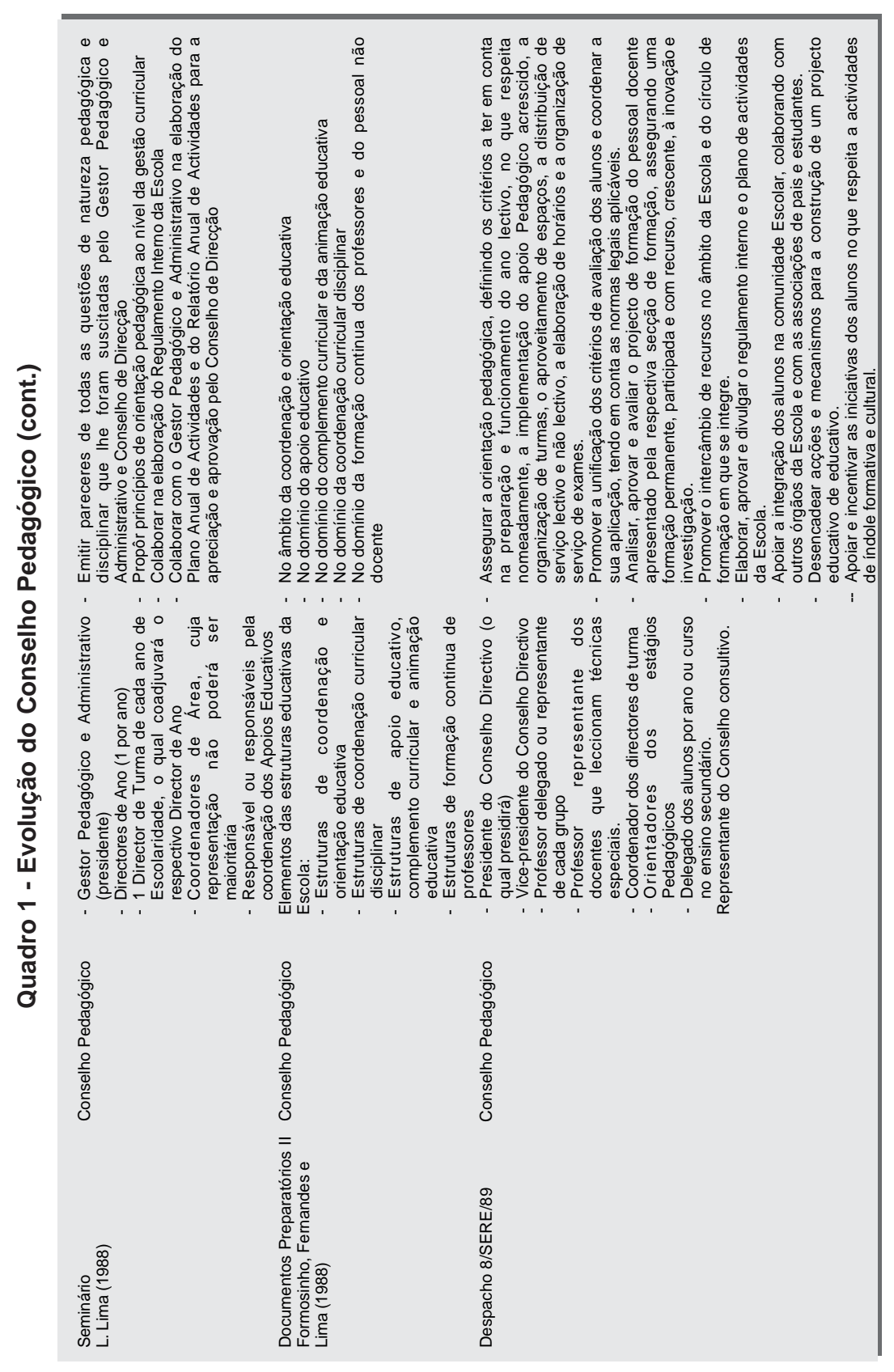



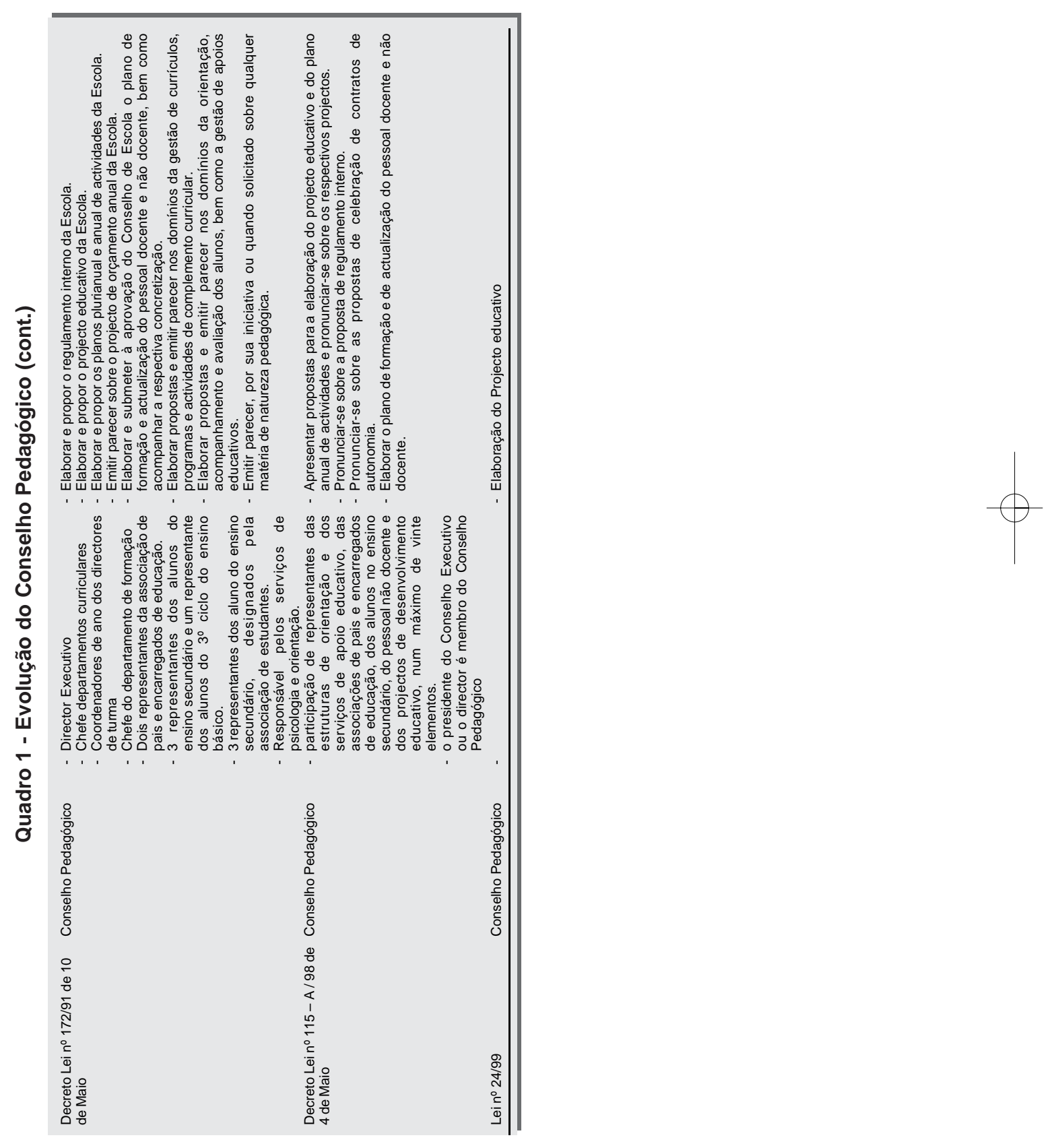
Representando um dos órgãos de topo das Escolas, o Conselho Pedagógico constitui, desde a sua génese, um órgão colegial de gestão central das Escolas. A partir da década de 90, com a publicação do DecretoLei no 115-A/98 emerge um novo órgão das Escolas: Assembleia de Escolas/Agrupamento, supostamente definido como órgão de "direcção" das Escolas. A partir de então, e no plano formal, os órgãos de topo das Escolas deveriam passar a ser subordinados hierárquicos da Assembleia de Escola/Agrupamento.

Recorrendo ao nosso estudo de caso corroboramos esta hipótese a partir da leitura do seu organograma.

\section{Figura 1 - Organograma Formal do Agrupamento Alfa}

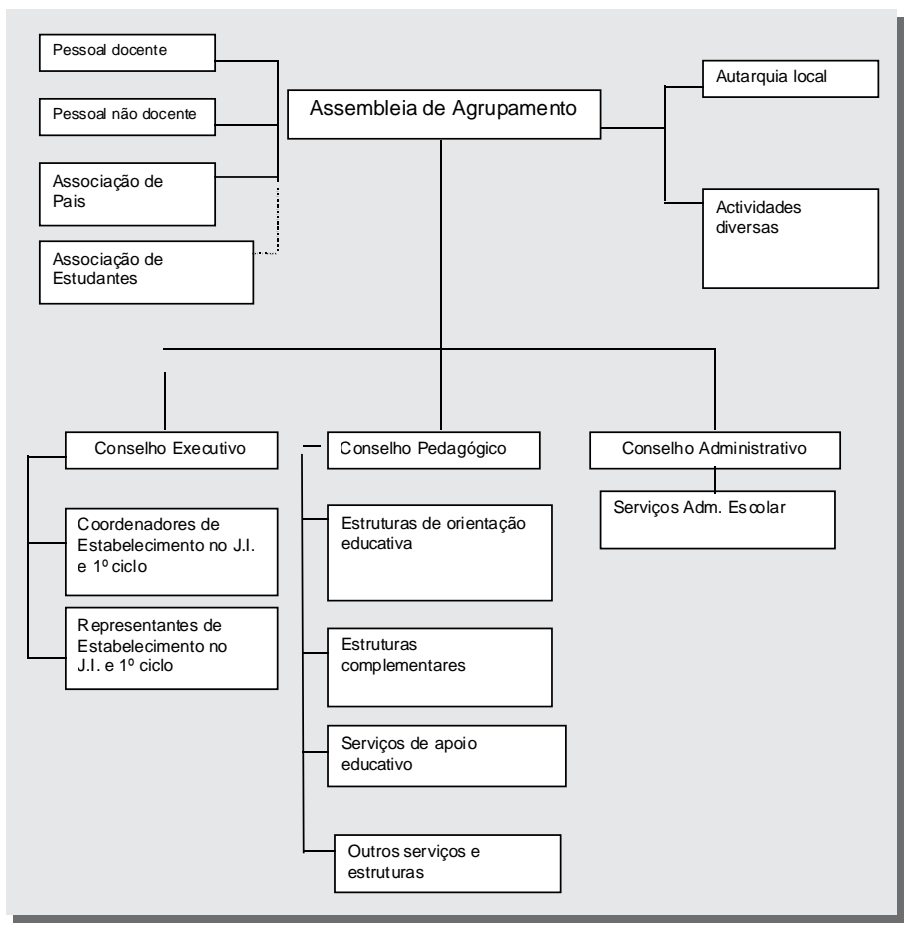

Fonte: Organograma formal reproduzido do Regulamento Interno do Agrupamento Alfa 
Reproduzindo o organograma da estrutura do Agrupamento em estudo (Alfa), conforme apresentamos (Figura 1), observamos que a Assembleia do Agrupamento é o órgão máximo, com mais projecção, o qual integra os diferentes elementos que compõem a comunidade educativa: pessoal docente, pessoal não docente, associação de pais, de estudantes, da autarquia local e das actividades diversas. O Conselho Executivo, o Conselho Pedagógico e o Conselho Administrativo surgem como órgãos subordinados à Assembleia do Agrupamento, situadas na mesma linha hierárquica. Em síntese, a representação apresentada define claramente o locus da autoridade orientado para a Assembleia de Escola, subalternizando os outros órgãos. No entanto, o desenho gráfico da estrutura formal possibilita-nos apenas uma leitura simplista das relações de poder, uma vez que apenas nos localiza os poderes formais.

No âmbito das competências atribuídas ao Conselho Pedagógico regista-se uma ampliação e evolução, conforme demonstramos no quadro 1. Sendo considerado o órgão que deve tomar decisões eminentemente pedagógicas, actualmente, decorrente sobretudo da última alteração ao

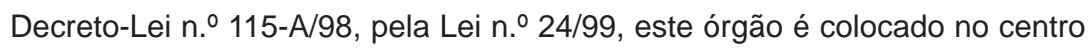
das políticas educativas locais ao responsabilizar-se pela elaboração do projecto educativo da Escola/Agrupamento. Assim, a este órgão, para além de se pronunciar e apresentar propostas sobre diferentes domínios pedagógicos e de formação contínua dos actores educativos, é cometida a responsabilidade da definição da política educativa da Escola/Agrupamento, competência esta que, decorrente da distinção teórica apresentada por Formosinho, Fernandes \& Lima (1988) entre direcção e gestão, se afigura mais coerente com um órgão de direcção, onde se encontra representada a comunidade educativa, do que um órgão considerado predominantemente de gestão. No entanto, na óptica da estrutura organizacional formal, o Conselho Pedagógico não adquire esta centralidade que Ihe é conferida legalmente.

No que se refere à composição deste órgão, percorrendo a legislação referida, verificamos que a sua representatividade é plural, tendo aumentado progressivamente desde 1974 até aos dias de hoje. O Conselho Pedagógico integra, a partir da década de 90, uma composição mais vasta, incorporando também representantes dos pais e encarregados de educação e representantes do pessoal não docente. Tendo em conta o nosso estudo, no 
50 Daniela Vilaverde e Silva

Agrupamento Alfa, o Conselho Pedagógico é composto pelos seguintes representantes, expressos no quadro 2 .

\section{Quadro 2 - Composição do Conselho Pedagógico}

\begin{tabular}{|l|l|}
\hline $\begin{array}{l}\text { Representantes dos Departamentos } \\
\left(2 .{ }^{\circ} \text { e 3.․ Ciclos) }\right.\end{array}$ & Língua Portuguesa \\
\hline & Ciências Sociais e Humanas \\
\hline & Línguas Estrangeiras \\
\hline & Ciências Exactas \\
\hline & Ciências Físicas e Naturais \\
\hline Um representante docente do pré-Escolar & Artes e Tecnologia \\
\hline Dois docentes do 1. ${ }^{\circ}$ Ciclo & Educação Física e Desporto \\
\hline Um Coordenador dos Directores de Turma \\
\hline Um representante das Actividades de Enriquecimento Curricular \\
\hline Um representante dos Serviços de Apoio Educativo \\
\hline Presidente do Conselho Executivo \\
\hline Um representante dos Pais e Encarregados de Educação \\
\hline Um representante do Pessoal Não Docente \\
\hline
\end{tabular}

A leitura do quadro permite aferir que a maioria dos membros deste Conselho é composta por docentes pertencentes ao 2 e 3 ciclos (73\%), registando-se um predomínio destes docentes face aos restantes elementos do Conselho.

\subsection{A autoridade e a influência do Conselho Pedagógico}

A compreensão do funcionamento e das dinâmicas intrínsecas ao Conselho Pedagógico, por parte dos actores que o compõem, implica uma (re)leitura inscrita, predominantemente, num plano mais informal, ancorado numa focalização mais micropolitica, na qual o conceito de poder ocupa um papel central na desocultação de certas lógicas de acção.

Na Figura 1 observamos que no âmbito das "orientações para a acção" (Lima, 1992: 159), o poder de autoridade se concentrava na Assembleia do Agrupamento. Na nossa investigação, pretendíamos conhecer até que ponto 
os docentes corroboravam este pressuposto formal, já que o "reconhecimento da autoridade formal é apenas uma das fontes de poder" (Estêvão, 1998: 184). Assim, quando inquirimos os professores sobre qual o órgão que possuía mais poder no Agrupamento, as respostas obtidas contradizem estes pressupostos teórico-formais. Neste sentido, pudemos apurar que a maior parte dos docentes que responderam a esta questão direccionou a sua resposta para o Conselho Pedagógico $(40,4 \%)$, seguido do Conselho Executivo (36,8\%). Com uma menor percentagem de resposta surge a Assembleia do Agrupamento (22,8\%), como observamos no seguinte gráfico:

\section{Gráfico 1 - Órgão com mais Poder de Influência}

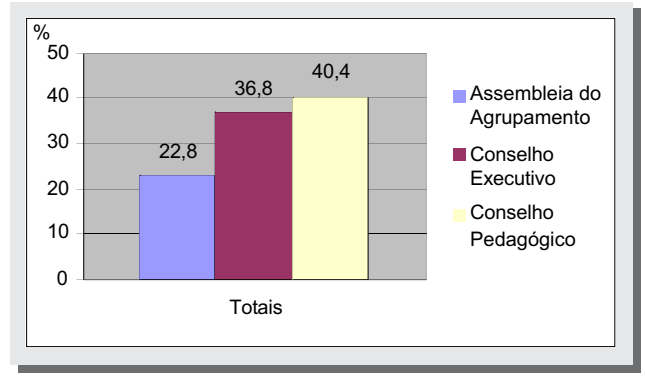

Numa primeira análise, podemos afirmar que o plano das orientações para a acção se encontra "debilmente articulado" com o plano da acção propriamente dita. Assim, dos dados obtidos destaca-se a ausência de correspondência entre o poder de autoridade, conferido à Assembleia do Agrupamento, e o poder de influência deste órgão, pois é aquele que se encontra mais despojado de poder a favor do Conselho Pedagógico e do Conselho Executivo ${ }^{12}$. Neste sentido, os actores Escolares dotam o Conselho Pedagógico de vários tipos de poder. Por um lado, reconhecem que 0 Conselho Pedagógico tem um poder de tomar decisões com base na especialização, como podemos observar pelo seguinte excerto:

Penso que é o Conselho Pedagógico, embora o Executivo possa, evidentemente, sobrepor-se mas o Conselho Pedagógico tem muita importância porque está toda a Escola representada nele e envolve uma componente que é fundamental, que é a componente pedagógica. Para além disso, trabalha estritamente com o Executivo. Há influências, há apoios (Excerto da entrevista ํㅜㄹ). 
Este actor faz referência à especialização deste órgão, à componente pedagógica, central na prática docente. Da mesma forma, também evoca a colegialidade, através da representação dos diferentes actores da Escola nesse mesmo órgão, como factor de poder, o que nos remete para a noção de colectivo (negligenciando a colectividade da Assembleia do Agrupamento).

Para além destas argumentações, ponderamos também uma outra hipótese justificativa dos dados, corroborada por Lima (1992: 421), na qual o Conselho Pedagógico "pode ser visto como o sucessor do plenário de professores, um órgão deliberativo exclusivamente formado por docentes" no qual "há mais discussão mas há, também, um pendor muito mais deliberativo [em relação ao Conselho Directivo]". Partindo desta ideia, consideramos que a situação transcrita se pode transpor para o nosso estudo, no qual a tradição e a composição exclusivamente/predominantemente docente constituem variáveis que não devem ser negligenciadas na interpretação destes dados.

Por outro lado, encontramos também outros tipos de argumentações que confirmam o poder do Conselho Pedagógico, nomeadamente a periodicidade e a duração das reuniões deste órgão face à Assembleia do Agrupamento:

O Conselho Pedagógico é um órgão que tem a participação de todos os grupos e isso cria um certo poder e uma certa credibilidade e até se pensarmos que o Conselho Pedagógico reúne mensalmente e que as reuniões começam às $15 \mathrm{~h}$ e acabam às $20 \mathrm{~h}$ enquanto as reuniões da Assembleia de Escola são feitas a correr, só por isso acho que se nota como as coisas são diferenciadas a nível do Pedagógico e muito dificilmente a assembleia vai questionar ou se vai impor às decisões do Pedagógico (Excerto da entrevista no 1).

O segundo órgão com mais poder de influência é o Conselho Executivo. A presença da presidente deste órgão constitui uma referência central no funcionamento do Conselho Pedagógico, não só porque grande parte da informação era divulgada por este elemento, mas também pela dinâmica que imprimia no funcionamento do órgão a par com o presidente do Conselho Pedagógico. Podemos dizer que se tratava de uma gestão quase em parceria ${ }^{13}$. Desta forma, verificamos, sobretudo, uma forte cooperação entre Conselho Pedagógico e Conselho Executivo ${ }^{14}$.

A pluralidade de actores de que se reveste o Conselho Pedagógico vem suscitar algumas interrogações sobre a multiplicidade de interesses e desigualdades nas representatividades dos membros que o compõem. Desta 
forma, procuramos reflectir sobre o seu modo de funcionamento. De acordo com as nossas 'notas de campo' e as entrevistas realizadas aos professores, parece-nos existirem indícios de que a consensualidade entre os actores é a tónica mais dominante, conforme afirma o seguinte entrevistado:

É confortável para mim pensar que é um órgão onde há, sem dúvida nenhuma, um clima de colaboração, não há situações de conflitualidade. No Conselho Pedagógico sinto que estamos todos ali a trabalhar para o mesmo, embora tenha que dividir tarefas, há sempre essa questão. Acaba por ser sempre difícil encontrar quem faça isto mas também porque são sempre as mesmas pessoas a desempenhar determinadas funções/tarefas na Escola. Há um clima pacífico, o que é bom, há relações cordiais (Excerto da entrevista no 2).

Apesar desta aparente cooperação, questionamos também alguns docentes sobre o domínio das relações de poder, típicos de órgãos colegiais. Desta forma, tendo em conta o âmbito das relações entre docentes dos diferentes departamentos curriculares, é possível afirmar que não há conflitos nessas relações, conforme pode deduzir-se destes depoimentos:

Parece-me que neste momento não há qualquer tipo de distanciamento porque temos coordenadores, nos departamentos há coordenadores do $2^{\circ}$ e $3^{\circ}$ ciclos e, no fundo, as funções, as tarefas são as mesmas, pelo que acho que essa questão está perfeitamente esclarecida (Excerto da entrevista $\mathrm{n}^{0} \mathbf{1}$ ).

Eu penso que é equilibrado em termos de poder. Cada um tem a sua opinião mas é tudo decidido pela maioria (Excerto da entrevista $\mathrm{n}^{\circ} 3$ ).

Este "equilíbrio" é, todavia, contestado pelos docentes que não representam departamentos curriculares e não pertencem ao $2^{\circ}$ e $3^{\circ}$ ciclos:

mesmo dentro de cada departamento, vemos um e outro departamento, cada um a 'puxar a brasa para a sua sardinha'. Eu entendo, entendo porque há determinadas realidades mas nota-se uma certa divergência (Excerto da entrevista $\mathrm{n}^{\circ} \mathrm{4}$ ).

Esta posição parece evidenciar a defesa de uma tomada de posição directamente relacionada com interesses de um determinado departamento curricular. Contudo, esta ideia não é consensual. A negação deste pressuposto é feita, sobretudo, pelos docentes do $2^{\circ}$ e $3^{\circ}$ ciclos deste Conselho, sendo até refutado à luz da emergência do poder carismático que alguns membros possuem. Inscreve-se nessa linha este depoimento:

Eu acho que não há representantes com mais poder, há sim capacidade argumentativa maior ou menor. Há pessoas que são mais capazes e essa capacidade evidentemente que lhes dá poder. Se os meus argumentos são, por 
regra, argumentos de peso, dificilmente rebatidos, então eu tenho poder. Eu penso que é nessa linha. Eu lembro-me que aqui há uns anos, havia uma pessoa que tinha um poder extraordinário nesta Escola. Eu acho que ela nem consciência, por vezes, tinha do poder que tinha e deixou marcas aqui na Escola, precisamente porque tinha uma capacidade de expor o que achava de uma maneira tão forte, tão expressiva que era muito difícil qualquer pessoa opor-se-lhe. Não é que fosse impossível, como é evidente, mas muitas das suas opiniões eram as que vingavam na Escola (Excerto da entrevista no 2).

Contudo, decorrente da formação dos Agrupamentos de Escola, importava também esclarecer a forma como os docentes se relacionavam tendo em conta as diferentes representatividades de ciclos e jardins de infância. Neste âmbito, as posições evidenciadas já não são tão unânimes. $A$ 'abertura' dos docentes que pertencem à Escola-sede aos do 1ํciclo e jardim de infância não foi imediata, conforme testemunho de vários actores:

sei que no início houve um sentimento um pouco estranho e sei também que há pessoas que ainda mantêm a ideia de que se tivéssemos só nós, segundo e terceiro ciclos, que era muito melhor. Mas penso que pouco a pouco as pessoas estão a abrir mais (Excerto da entrevista $\mathrm{n}^{\circ}{ }^{2}$ ).

Entre os diferentes níveis as relações são um pouco diferentes porque a experiência das pessoas é diferente. Quando é necessário - e têm sido feitos várias vezes - trabalhos, no qual tenho participado, também participam elementos dos diferentes ciclos e isso cria uma aproximação. À partida, há um distanciamento na forma de ver as coisas, há metodologias, por vezes, diferentes. Sentimos isso quando trabalhamos, quando é necessário grupos com a presença dos vários níveis de ensino. Acho que nos estamos a aproximar com esses grupos de trabalho (Excerto da entrevista $n^{0} 1$ ).

As relações entre docentes do $2^{\circ}$ e $3^{\circ}$ ciclos e docentes do $1^{\circ}$ ciclo e educadores de infância são aquelas onde a consensualidade no funcionamento do órgão é mais frágil. Há uma espécie de sentimento de 'ciclos' de interesse que predominam face os restantes ciclos, como constatamos nas observações efectuadas e no discurso da seguinte docente:

o pré-escolar e o $1^{\circ}$ ciclo falam um bocadinho. Quando há um problema maior, é necessário mais tempo para discutir esse assunto entre o pré-escolar e 01 은 ciclo e é complicado porque temos muitas provas. Temos isto no Pedagógico! Não há um Agrupamento de Escolas no Pedagógico. Há um $2^{\circ}$ e $3^{\circ}$ ciclo e pronto há o ouvir do $1^{\circ}$ ciclo e do pré-escolar (Excerto da entrevista $n^{\circ}{ }^{\circ}$ ).

No entanto, a mesma docente procura justificar esta desigualdade de poderes entre os ciclos no Conselho Pedagógico: 
acho que eles $\left[2^{\circ} 3^{\circ}\right.$ ciclos] sentem que, como a representatividade que eles demonstram, estão a representar 800 e tal alunos, portanto, o tempo é muito superior e necessitam. Acho que eles...é uma perspectiva um bocadinho individualista, vamos resolver os nossos problemas. Os outros do $1^{\circ}$ ciclo e pré Escolar se não for de uma forma é de outra, vamos primeiro aos nossos problemas porque são 800 e tal e têm que ser resolvidos. Eu acho que é um bocado isso (Excerto da entrevista no 4 ).

Para além do peso da representatividade de alunos de cada ciclo, outro actor justifica este facto sob a argumentação de que o funcionamento entre os ciclos é diferente, referindo que os docentes do $2^{\circ}$ e $3^{\circ}$ ciclos ainda não integraram as formas de trabalhar ${ }^{15}$ do $1^{\circ}$ ciclo:

entre o $2^{\circ}$ e $\circ 3^{\circ}$ ciclo e em relação ao $1^{\circ}$ ciclo, portanto, a filosofia é diferente e eles por vezes há coisas que ficam admirados porque não entendem, não têm conhecimento, estão a entrar, estão ainda a começar a conhecer a realidade do 1 ciclo no aspecto das retenções, na forma de avaliação dos alunos, do sistema de trabalho, na parte administrativa também, principalmente, portanto, o sistema de faltas das crianças, os dossiers. Nós fazemos esse trabalho de outra forma que não a deles. É aí que residem os pontos mais divergentes (Excerto da entrevista ํㅜ 6).

As idiossincrasias de cada ciclo e a defesa da sua identidade poderão ser interpretadas como uma forma de resistência à abertura das relações entre os ciclos. Os diferentes interesses de ciclos parecem circunscrever-se à volta de si próprios, como que fechados, face aos outros. No entanto, e decorrente da formação do Agrupamento, a identidade de cada ciclo/Escola vai sendo paulatinamente desvanecida em prol da construção da identidade do Agrupamento, onde os docentes do $1^{\circ}$ ciclo e jardins de infância se têm vindo a integrar na forma de funcionamento do $2^{\circ}$ e 3 o ciclos. É o que nos diz esta entrevistada:

Muitas vezes, sente-se que a maneira de trabalhar é um bocadinho diferente. $O$ Jardim, por vezes, trabalha mais à maneira do $3^{\circ}$ e do $2^{\circ}$ ciclo do que trabalha o 1ํㅗำlo mas não há uma ligação directa sobre isso. Lentamente, eu penso, aqui neste caso, existe mesmo um consenso entre os professores, tem-se conseguido integrar. Acho que estamos todos a trabalhar de maneira muito mais uniforme, sem fazer quebras assim radicais, em relação ao método de trabalho, temos abraçado projectos que achamos vão ser interessantes (Excerto da entrevista no 9).

É interessante registar que este excerto vem salientar os diferentes poderes entre os ciclos, onde é valorizada a forma de trabalhar do $2^{\circ}$ e $3^{\circ}$ 
ciclos em detrimento dos outros ciclos ${ }^{16}$. Esta assimetria de poderes entre ciclos constitui um indicador de indícios da existência dentro do mesmo órgão de relações de subordinação/predomínio, que, embora não seja feita de forma clara, poderá colocar em causa a democraticidade do próprio órgão.

Do ponto de vista administrativo, importa destacar alguns discursos por parte dos docentes dos jardins de infância e $1^{\circ}$ ciclo que focalizam a centralidade administrativa na Escola-sede do Agrupamento, como por exemplo:

a Escola [ $1{ }^{\circ}$ ciclo] resolvia logo o problema [...] a junta de freguesia atribuía um $X$ à Escola e a Escola geria conforme a necessidade. Através do Agrupamento é tudo mais... pronto... tenho de pedir tudo, não é? O que é normal.[...] tem de se pedir primeiro ao Agrupamento. Imaginemos que queremos comprar umas colas que de momento não há, tem de se aguardar, pedir [...] à Escola sede. Esperar aquele tempo todo até que acabamos por desanimar e até nós fazermos o que realmente a Escola necessita... isto é um exemplo [...] é aí que eu acho que ... [em termos financeiros] perdeu a favor do Agrupamento. É mesmo assim, a situação é mesmo empurrada para aí... nem o Agrupamento tem culpa... é o próprio sistema que está assim ... exige que assim seja (Excerto da entrevista $\mathrm{n} \div$ 7).

Reflectindo sobre a 'voz' deste actor, registamos essencialmente duas dimensões: a perda da 'frágil' 'autonomia' da gestão financeira da Escola do 1ㅇ ciclo e, decorrente desta, a crescente centralidade administrativa da "Escola-sede". Esta leitura vai ao encontro da proposta teórica de Lima (2004: 42) quando refere que "os Agrupamentos de Escolas representam, de acordo com a política seguida e as opções organizacionais tomadas, um novo escalão da administração central-desconcentrada, operando a partir da Escola-sede, mais proximamente e imediatamente sobre as Escolas-outras".

Tendo em conta os diferentes actores não docentes presentes no Conselho Pedagógico, procuramos, nas entrevistas realizadas aos docentes, conhecer a representação que estes tinham sobre o poder deliberativo do representante da Associação de Pais e dos Encarregados de Educação e do representante do pessoal não docente.

No que diz respeito ao elemento da Associação de Pais e dos Encarregados de Educação no Conselho Pedagógico, os docentes consideram que

tem tido sempre uma presença bastante positiva embora surjam algumas críticas, como surgiu no último Pedagógico. Normalmente, a atitude dele é uma 
atitude de colaboração com a Escola, de participação com os diferentes grupos de trabalho, acho que isso é muito louvável. É muito importante. Em todos os projectos, que têm sido elaborados, eles têm estado presentes. Isso é óptimo porque sentem que é o trabalho deles, o que sai a nível dos documentos da Escola é também o resultado da participação dos pais. Acho que é muito positivo (Excerto da entrevista no 1 ).

Aqui nesta entrevista, define-se a forma como os professores representam a participação deste elemento. Nas reuniões observadas, 0 elemento da Associação de Pais e dos Encarregados de Educação presente participava sempre, mesmo quando não era solicitado. A postura observada era sempre crítica, mas colaborante em relação ao trabalho dos professores. Daí que os professores considerem que a sua participação:

é muito importante e acho que a Escola durante muitos anos funcionou um bocado tendo como pressuposto que só os professores é que sabem, só eles é que devem tomar decisões, e no fundo, já usavam de uma certa autonomia para a qual certamente até nem estavam mandatados mas até era normal porque não podíamos estar a perguntar, a fazer esta ou aquela pergunta, há coisas que a gente tem de decidir. [...] Eu acho que é bom que os professores cada vez mais sejam capazes de ouvir os pais [...] têm o direito de saber o tipo de educação que o seu filho recebe, nomeadamente ao nível dos valores (Excerto da entrevista ํㅜ 2).

A importância da participação dos pais parece justificar-se à luz de uma maior 'proximidade' entre pais e professores na qual a resolução de eventuais conflitos pode ser atenuada. No entanto, no que se refere ao poder em termos deliberativos destes elementos no Conselho Pedagógico, esta participação torna-se mais complexa, como nos explica o seguinte docente:

Em relação ao Pedagógico, eu penso que quando mexo com algumas trocas de professores há uma tentativa de 'desculpar' e de explicar o procedimento do professor, etc. Não me parece que um pai depois possa alterar grande coisa ou possa dizer muito mais do que aquilo que depois é supostamente explicado. Como viu neste caso do pai que questionou os testes, por exemplo. Os professores acabam por aceitar, basicamente, o que os pais dizem mas depois na prática não muda muito porque é uma questão já antiga. [...]. No meu ponto de vista, o homem tinha razão mas é difícil de assumir esse tipo de coisas (Excerto da entrevista no 9).

Apesar da participação do elemento da Associação de Pais ser considerada, pelos docentes entrevistados, importante e com base nos dados da observação, podemos considerá-la activa ${ }^{17}$, o facto é que, ao analisarmos as relações de poder endógeno ao órgão, esta participação perde visibilidade 
no processo de tomada de decisões, o que pode representar uma espécie de ilusão, "encenação" participativa (Lima, 1992). Para além disso, existem indícios do recurso a estratégias defensivas por parte dos professores face situações de discordância deste elemento.

Em relação ao representante do pessoal não docente, os professores consideram:

A participação é, sem dúvida, que é importante. Só que realmente nas questões mais a nível de pedagogia, de decisões importantes na Escola, normalmente o representante do pessoal não docente que tem assento no Pedagógico tem uma participação muito reduzida e portanto se calhar não é nesse sentido. Normalmente, as questões que levava ao Pedagógico, e nem estou só a pensar neste ano, eram questões mais práticas, vividas, sentidas por eles e não questões que envolvessem toda a Escola. A presença dele tem a ver muito com questões que só a eles dizem respeito, a participação deles é muito reduzida (Excerto da entrevista $n^{0} 1$ ).

A participação deste elemento ao longo do ano lectivo neste órgão foi, de acordo com as 'notas de campo'18 passiva. Este elemento apenas se pronunciou quando solicitado, daí que o docente acima tenha considerado a sua participação "muito reduzida". Na procura de uma justificação para este tipo de participação, um dos docentes entrevistados considerou que este facto se deve a um défice de formação deste elemento em relação aos assuntos abordados neste órgão:

Isto tem a ver precisamente com a formação que o pessoal auxiliar deveria ter. Já reparou certamente que a participação da representante actual é muito pouca, imagino que não se sinta muito por dentro das questões. Evidentemente num meio que é dominado por professores, poder haver alguma dificuldade por parte dela, algum receio, não sei. Eu acho que devia ser alguém que tomasse posição, que manifestasse posição, mas para isso é preciso saber, é preciso ter capacidade [...] que eles são importantes! E deveriam ser capazes de prestar um serviço que passa muito para além da limpeza e a maior parte dos nossos funcionários estão nitidamente vocacionados para a limpeza e quando é necessário ir um pouquinho além da limpeza, como a acção pedagógica serena juntos dos alunos, aí é que as dificuldades se sentem (Excerto da entrevista $n^{\circ}$ 2).

Apesar de esta participação ser bastante passiva, e sem poder deliberativo, em termos discursivos os docentes entrevistados consideram-na importante, no sentido em que constituem também agentes educativos presentes na organização Escolar. 


\section{Em jeito de conclusão}

Neste artigo reflectimos sobre algumas dimensões situadas quer no plano das orientações da acção quer no plano da acção concreta que nos permitiram desvendar a desarticulação entre estes dois planos de análise organizacional, tendo em conta os tipos de poder de autoridade formal e de influência. Assim, registamos que o Conselho Pedagógico, apesar de constituir, na estrutura formal, um órgão subordinado à Assembleia do Agrupamento, no plano da acção concreta o mesmo emerge como o órgão que congrega vários tipos de poder de influência, o qual, do ponto de vista informal, é representado como o órgão com mais poder influência no Agrupamento, segundo os docentes do Agrupamento Alfa. A leitura destes dados pode ser compreendida à luz da perspectiva teórica de Crozier \& Friedberg (1977) quando consideram que a especialização, neste caso do Conselho Pedagógico, pode ser uma fonte de poder na organização em virtude do conhecimento/função que revela.

No que diz respeito ao funcionamento do Conselho Pedagógico, os dados observados indicam-nos que existem diferentes relações de poder entre os seus membros, salientando nesta relação o predomínio dos docentes, sobretudo do $2^{\circ}$ e $3^{\circ}$ ciclo que estão em maioria no processo de tomada de decisões, em relação aos outros representantes, nomeadamente docentes do $1^{\circ}$ ciclo e educadores de infância, representantes dos pais/encarregados de educação e representantes do pessoal não docente. Desta forma, parece existir entre os diferentes representantes docentes um sentimento de pertença que se divide entre "nós" ( $3^{\circ}$ e $2^{\circ}$ ciclos) e "eles" (1ํㄷclo e jardim de infância), como se este Conselho fosse composto por vários núcleos. Para além disso, a presença dos actores não docentes, embora discursivamente importante para os docentes, carece de capacidade de decisão, nomeadamente a participação dos auxiliares de acção educativa.

Neste contexto, urge repensar as fragilidades democráticas quer legais quer na acção concreta deste órgão. Assim sendo, interrogamos se a representatividade legal desigual (numérica/(in)formação) entre os representantes $\left(^{\circ}\right.$ e $3^{\circ}$ ciclo; $1^{\circ}$ ciclo, educadores de infância, pais/encarregados de educação e representantes do pessoal não docente) não poderá ser um factor condicionador das práticas democráticas? 
A centralidade administrativa da Escola-sede, a qual vem reforçar uma agenda centralizadora desconcentrada da Administração Escolar, traduz-se no seio de uma organização Agrupamento como mais uma perda de poder das "Escolas-outras" a favor da Escola-sede, nomeadamente na parte financeira e no quotidiano escolar através da uniformização de práticas e procedimentos. A ideia que trespassa dos dados de investigação é a de que o próprio Decreto-Lei no 115-A/98 ao fomentar a constituição dos Agrupamentos de Escolas está a cercear a frágil margem de autonomia relativa dos actores escolares e, seguindo a perspectiva de Lima (2004), a conceber um centro de gestão de várias escolas agrupadas, o qual representa o último escalão hierárquico da administração desconcentrada. Contudo, é de registar que o fortalecimento da centralização administrativa desenvolve-se num contexto legal proporcionado pelo Decreto-Lei no 115-A/98 o qual, paradoxalmente, 'proclama' a 'autonomia' das Escolas.

A pertinência em convocar o campo disciplinar da sociologia das organizações, nomeadamente do modelo político, revelou-se, neste estudo, de particular importância, não só porque nos possibilitou desvendar algumas dinâmicas conotadas com uma focalização mais micropolitica de um dos órgãos de um Agrupamento de Escolas, mas, simultaneamente, esta focalização também nos remeteu para uma focalização mais macro, a qual nos permitiu compreender o impacto entre estes dois planos de análise que interactuam e influenciam mutuamente.

\section{Notas}

1 Concretamente: a) 9 entrevistas aos membros do Conselho Pedagógico, as quais foram submetidas ao tratamento de análise simples de conteúdo; b) inquérito por questionário a todos os docentes de todos os ciclos do Agrupamento, no qual obtivemos uma amostragem de 50,4\% face ao universo pretendido, tendo os dados sido tratados no programa estatístico Statistical Package for the Social Science (SPSS). A aplicação do questionário ocorreu no terceiro período do ano lectivo, nos meses de Maio e Junho de 2003; c) observação directa de 8 reuniões do Conselho Pedagógico durante 0 ano lectivo 2002/2003 (com cerca de 5 horas de duração cada). Os dados obtidos pela observação foram estruturados no nosso "diário de campo", no qual anotávamos o dia da observação, local e diversas expressões proferidas pelos/entre os docentes observados; d) análise documental que ocorreu ao longo do ano lectivo em que decorreu a investigação e consistiu na pesquisa de determinados documentos como: o projecto educativo e o regulamento interno do 
Agrupamento, o plano anual de actividades, o projecto curricular de Agrupamento. Posteriormente, analisámos também as actas relativas às reuniões do Conselho Pedagógico. A consulta das actas foi efectuada na Escola sede do Agrupamento, sobretudo na biblioteca. Após a leitura de cada acta registámos e transcrevemos os aspectos mais pertinentes para a nossa investigação; e e) conversas informais com os diferentes professores do Agrupamento de Escolas em estudo, as quais foram importantes para compreender muitos dos acontecimentos e práticas dos mesmos. Para aprofundar a componente metodológica ver Silva (2004).

2 A autora justifica a distinção entre estes dois planos de abordagem do modelo da seguinte forma: "a análise crítica da organização escolar vai mais além das dinâmicas micropolíticas desenvolvidas dentro da escola explorando [também] as coordenadas sócio-económicas, políticas e ideológicas nas quais se desenvolve a organização e com as que mantém relações dinâmicas e dialécticas [...] A visão crítica sublinha que a organização, tanto na sua estrutura como no seu funcionamento, não é independente do contexto e das forças extraorganizacionais que a afectam e as que, de alguma forma, afecta" (González González, 1993: 184).

3 De acordo com Blase (1991), os estudos desenvolvidos por lannaccone (1970, cit. por Blase, 1991) nas Escolas públicas possibilitaram a conceptualização da abordagem micropolítica de duas formas distintas: por um lado, no âmbito das interacções entre administradores, professores e estudantes (subsistema interno da organização; por outro lado, as interacções entre a lei e o subsistema profissional dos professores no âmbito Escolar. Segundo o autor, as acções de cada subsistema influenciam-se mutuamente e o recurso à análise micropolítica potencia "o conhecimento das exigências de autonomia dos professores e a forma como essa ideologia política e essas exigências interagem com os interesses dos administradores Escolares e com o público" (Blase, 1991: 7-8).

4 Como afirma Friedberg (1995: 116) "o poder está em todo o lado, faz parte das coisas que preparamos todos os dias e de que somos quotidianamente também o objecto".

5 Nesta acepção Friedberg (1995) continua a diferenciar autoridade (imbuída de poder formal) de poder: "A relação de autoridade é o exemplo bem conhecido de uma relação transitiva: numa cadeia hierárquica, o topo $\mathrm{A}$ tem, dada a sua posição, autoridade sobre B, C e D que são todos seus subordinados. As coisas são diferentes na relação de poder. Não é pelo facto de $A$ ter poder sobre B nas suas transacções com ele que dispõe automaticamente desse poder sobre $\mathrm{C}$, mesmo que $\mathrm{C}$ seja subordinado de $\mathrm{B}$. Tudo depende da relação concreta e específica que se estabelecer entre A e $C$ na qual o poder sobre B não é necessariamente nem automaticamente um recurso pertinente" (p. 116).

6 Existe uma variedade no âmbito da sociologia organizacional das fontes de poder adoptadas por vários autores. Ao optarmos por apresentar esta tipologia de Crozier \& Friedberg, direccionamos a nossa análise para procurar agrupar as várias fontes de poder que encontramos na literatura da sociologia das organizações. No entanto, não podemos deixar de assinalar outro contributo importante fornecido por Morgan (1996) acerca das catorze fontes de poder, que são: 1. autoridade formal; 2. controlo de recursos escassos; 3 . utilização da estrutura organizacional, leis e regulamentos; 4 . controlo dos processos de decisão; 5 . controlo do conhecimento e 
da informação; 6. controlo de limites; 7. capacidade de lidar com as incertezas; 8 . controlo da tecnologia; 9. alianças inter-pessoais, comunicações e controlo da "organização-informal"; 10. controlo das contra-organizações; 11. simbolismo e manipulação de ideias; 12 . sexo e controlo das relações de sexo; 13. factores estruturais definidores do cenário de acção; 14. o poder em posse.

7 Segundo estes autores, "o poder está inseparavelmente ligado à negociação" (Crozier \& Friedberg, 1977: 66).

8 Os autores procuram explicar este tipo de relação através das seguintes fórmulas: "se A pode facilmente obter de B a acção X e B pode obter a mesma acção de C, pode-se todavia supor que A seja incapaz de obter de C [...] Assim, A obterá facilmente de $B$ a acção $X$, mas dificilmente a acção $Y$ e será impossível obter a acção Z que uma outra pessoa C obterá facilmente" (Crozier \& Friedberg, 1977: 68).

9 Explicitando através das fórmulas adoptadas pelos autores, podemos compreender melhor a reciprocidade das relações. "Se B não pode explicar a sua vontade de fazer o que $A$ pede, não pode haver mais uma relação de poder entre os dois, pois B deixa de existir enquanto actor autónomo face a A para se tornar uma coisa" (Crozier \& Friedberg, 1977).

$10 \mathrm{Na}$ análise das organizações A. Etzioni (1972) apresenta três tipos de organizações que derivam de três tipos de controlo e de poder. Consoante o tipo de controlo organizacional mobilizado para conseguir que a acção dos membros seja congruente com os objectivos, regulamentos previamente definidos, as organizações podem ser: a) coercivas, onde o meio de controlo é a aplicação de sanções, recorrendo-se ao poder coercivo; b) utilitárias, nas quais as recompensas são materiais com o recurso ao poder material; c) normativas, onde o meio de controlo e o poder é normativo, implicando a obediência às regras da organização. Nesta tipologia, o poder é perspectivado como um instrumento de controlo da organização. A diferenciação destas organizações não significa que as fronteiras entre elas sejam estanques; antes pelo contrário. Etzioni prevê a existência de uma organização que absorva os três tipos de poder, exemplificando com as organizações sindicais.

11 A aplicação dos estudos dos fenómenos de poder à organização Escolar foi já alvo de diferentes estudos, abordando sobretudo os diferentes tipos de poder mobilizados pelos professores. Entre eles, destacamos Formosinho (1980) e Afonso (1991). Este último apresenta, na confluência do âmbito da micro-sociologia educacional da sala de aula, a destrinça entre o poder formal (ligado ao conceito de autoridade - poder de cargo) do professor e o poder informal representado pelos alunos (que segundo as teorias clássicas se encontram ávidos de poder). Os autores desenvolveram as suas tipologias de poder com base nos estudos de French \& Raven que identificam cinco fontes de poder: poder de recompensa, poder coercivo, poder legítimo, poder de referente, poder de especialista (Afonso, 1991: 25).

12 No âmbito do "Programa de Avaliação externa do processo de aplicação" do Decreto-Lei n. 0 115-A/98, coordenado por J. Barroso, os estudos levados a cabo concluíram que dos presidentes do Conselho Executivos inquiridos, o Conselho Pedagógico "ainda que informalmente, [é o] órgão central no processo de tomada de decisões na Escola" (Afonso \& Viseu, 2001: 67). De igual modo, os investigadores reconhecem também que "no que se refere ao Pedagógico, parece 
ter-se verificado uma estratégia de recomposição do poder tradicional deste órgão, que muitos professores (e suas organizações sindicais) julgaram ameaçado com este novo ordenamento jurídico da gestão Escolar" (Barroso, Almeida \& Homem, 2001: 105). Neste sentido, estes autores confirmam a ideia de que "pelas informações transmitidas, transparece a ideia que a Assembleia de Escola não passa de uma réplica menor do próprio Conselho Pedagógico" (idem, ibidem).

13 Esta posição contraria outros estudos de casos, em que a relação entre o Conselho Pedagógico e o antigo Conselho Directivo era definida pelo contra poder exercido pelo Conselho Pedagógico face às decisões do Conselho Directivo. A este propósito ver investigação de Lima (1992).

14 Este facto é também corroborado pela observação nas reuniões do Conselho Pedagógico, onde todos os elementos do Executivo estavam também presentes, conforme registámos no nosso 'diário de campo'. Além disso, a participação e as intervenções do Presidente do Conselho Executivo no Conselho Pedagógico era preponderante. Num estudo realizado por Dinis (1997) ao Conselho Pedagógico, o autor conclui que as reuniões "são centradas no presidente [simultaneamente presidente do Conselho Pedagógico e presidente do Conselho Directivo]. Mesmo naquela em que a sua intervenção é menor, ela representa mais do que a quarta parte. A importância do seu papel na dinâmica das reuniões surge ainda mais marcado se atendermos à produção e comunicações: ele é autor de mais de um terço das intervenções e de quase metade das comunicações [...]. Mais do que deliberativo, o Conselho é um órgão para o presidente do Conselho Directivo".

15 Também registámos nas 'notas de campo' alguma resistência de um dos representantes do $1^{\circ}$ ciclo face às reuniões do Conselho Pedagógico, afirmando que "não devia estar aqui" e demonstrando algum descontentamento perante 0 órgão ao longo do ano lectivo.

16 De acordo com as 'notas de campo' do Conselho Pedagógico do dia 20 de Novembro de 2002, uma das preocupações foi o debate sobre a uniformização das fichas de registo de avaliação, a comunicar aos pais, o que constitui mais um exemplo aglutinador da identidade da Escola a favor do Agrupamento. No entanto, registámos também que os professores consideram que "os pais gostaram mais desta forma, uma vez que quando os alunos passarem para o ciclo seguinte já estão habituados a esta ficha".

17 Segundo a tipologia de participação de Lima (1992).

\section{Referências}

AFONSO, Almerindo (1991). O Processo Disciplinar como Meio de Controlo na Sala de Aula. Braga: Instituto de Educação e Psicologia, Universidade do Minho.

AFONSO, Natércio \& VISEU, Sofia (2001). A reconfiguração da estrutura e gestão das escolas públicas dos ensinos básico e secundário: estudo extensivo. In $\mathrm{J}$. Barroso (org.), Relatório Global da Primeira Fase do Programa de Avaliação Externa. Relatório Sectorial 4. Lisboa: Centro de Estudos da Escola, FPCE/UL, pp. 60-74. 
ANDERSON, Gary \& BLASE, Joseph (1994). El contexto micropolitico del trabajo de los professores. In J. Escudero \& M. T. Gonzáles González, Professores Y Escuela: ¿Hacia Una Reconversión de los Centros Y la Función Docente? Madrid: Ediciones Pedagógicas, pp. 97-114.

BALL, Stephen (1994). La Micropolítica de la Escuela - Hacia una Teoria de la Organizacíon Escolar. Barcelona: Ediciones Paidós Ibérica/MEC.

BARROSO, João; ALMEIDA, Ana \& HOMEM, Luísa (2001). As Assembleias de Escola em discurso directo. In J. Barroso (org.), Relatório Global da Primeira Fase do Programa de Avaliação Externa. Lisboa: Centro de Estudos da Escola, FCPE/U, pp. 100-119.

BERGER, Peter (2000). Perspectivas Sociológicas. Uma Visão Humanista. Petrópolis: Vozes.

BLASE, Joseph (1991). The micropolitical perspective. In J. Blase (ed.), The Politics of Life in Schools. Newbury Park: Sage Publications, pp. 1-18.

BOLMAN, Lee \& DEAL, Terrence (1989). Modern Approaches to Understanding and Managing Organizations. San Francisco: Jossey-Bass.

BUSH, Tony (1995). Theories of Educational Management. London: Harper \& Row.

CROZIER, Michel \& FRIEDBERG, Erhard (1977). L'Acteur et le Systéme. Paris: Èditions du Seuil.

CROZIER, Michel (1963). Le Phénoméne Bureaucratique. Paris: Ėditions du Seuil.

DINIS, Luís (1997). "Para que servem os Conselhos Pedagógicos? Estudo de (um) caso de uma escola básica 2/3". In A. Luís; J. Barroso \& J. Pinhal (Eds.), Actas do $1^{\circ}$ Congresso do Fórum Português de Administração Educacional - A Administração da Educação: Investigação, Formação e Práticas. Lisboa: FPAE, pp. 265-293.

ESTÊVÃO, Carlos (1998). Redescobrir a Escola Privada Portuguesa enquanto Organização. Braga: Universidade do Minho, Instituto de Educação e Psicologia, Centro de Estudos em Educação e Psicologia.

ETZIONI, Amitai (1972). Organizações Modernas. São Paulo: Editora Livraria Pioneira.

FORMOSINHO, João (1980). As bases do poder do professor. Revista Portuguesa de Pedagogia, ano XIV, pp. 301-328.

FORMOSINHO, João; FERNANDES, António S. \& LIMA, Licínio (1988). Ordenamento Jurídico da Direcção e Gestão das Escolas. In CRSE, Documentos Preparátorios II, Lisboa: ME/GEP, pp. 171-236.

FRIEDBERG, Erhard (1995). O Poder e a Regra. Dinâmicas da Acção Organizada. Lisboa: Instituto Piaget.

GIROUX, Henry (1986). Teoria Crítica e Resistência em Educação. Petrópolis: Vozes.

GONZÁLEZ GONZÁLEZ, Maria Teresa (1993). Nuevas perspectivas en el análisis de las organizaciones Educativas. In J. GARÍN SALLÁN \& S. ANTUNES MARCOS (Coords.), Organización Escolar. Nuevas Aportaciones. Barcelona: PPU; pp. 159-193.

GONZÁLEZ GONZÁLEZ, Maria Teresa (1994). Perspectivas Teóricas Recientes en Organización Escolar: Una Panorámica General. In J. M. Escudero \& M. T. 


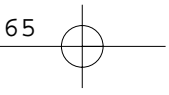

González González, Professores Y escuela: ?Hacia Una Reconversión de los Centros Y la Función Docente? Madrid: Édiciones Pedagógicas, pp. 35-59.

HOYLE, Eric (1988). Micropolitics of educational organizations. In A. Westoby (ed.), Culture and Power in Educational Organization. Milton Keynes: Open University Press, pp. 255-269.

LIMA, Licínio (1988). Modelos de organização das Escolas Básica e Secundária. In CRSE, A Gestão do Sistema Escolar. Lisboa: ME/GEP, pp. 149-195.

LIMA, Licínio (1998). A Escola como Organização e a Participação na Organização Escolar. Braga: Universidade do Minho, Instituto de Educação e Psicologia, Centro de Estudos em Educação e Psicologia.

LIMA, Licínio (2004). O Agrupamento de Escolas como administração desconcentrada. Revista Portuguesa de Educação, vol.7, no 2, pp. 7-47.

MORGAN, Garet (1996). Imagens da Organização. São Paulo: Atlas.

SÁ, Virgínio (1997). Racionalidades e Práticas na Gestão Pedagógica: o Caso do Director de Turma. Lisboa: Instituto de Inovação Educacional.

SILVA, Daniela (2004). Lógicas de Acção em Contexto de Autonomia - Estudo das Representações Docentes num Agrupamento de Escolas do Ensino Básico. Dissertação de mestrado em Educação. Braga: Universidade do Minho.

WEBER, Max (1991). Economia e Sociedade. Brasília: Edições Universidade de Brasília.

\section{Legislação}

Decreto-Lei $n . .115-\mathrm{A} / 98$, de 4 de Maio

Decreto-Lei n. $.735-\mathrm{A} / 74$, de 21 de Dezembro

Decreto-Lei n.. 769-A/76, de 23 de Outubro

Decreto Regulamentar n.. 12/2000, de 29 de Agosto

Despacho 8/SERE/89 de 8 de Fevereiro

Lei n. $024 / 99$, de 22 de Abril 


\section{POWER QUESTIONS IN PEDAGOGIC BOARD - REFLECTIONS FROM A CASE STUDY OF THE SCHOOLS GROUPING}

Abstract

This article focuses on a study that took place in the school year of 2002/2003. The study is about the different games of power and interests moved by the actors from one of the administrative structure of the public basic schools: the pedagogic board. The implementation of a legal system of administrating schools by the Decree Law nr 115-A/98 brought changes to the pedagogic board composition. Thus, the plurality of actors, due to both its legal composition and to the creation of the schools grouping, gave a more complexity to this board. From a case study in a schools' grouping, we pretend, on one hand, to analyse different powers among the pedagogic board members. On the other hand, to reflect on how the teachers see the participation of the different actors of this board. The data obtained from the investigation shows the existence of different relationships of power among the members of this board. The decisions, the procedures and practises adopted by the grouping mirror, above all, a greater predominance of the teachers' interests of the 2nd and 3rd cycles comparing with the kindergartens and teachers of the 1st cycle, developing, in this way, cycles' interests which may fragile dynamics connoted with the democratic logics.

Keywords

Pedagogic Board; Powers; Interests 


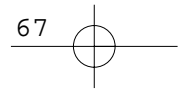

\section{QUESTIONS DE POUVOIR DANS UN CONSEIL PEDAGOGIQUE - REFLEXIONS A PARTIR D'UNE ENQUETE D'UN CAS DANS UN AGROUPEMENT D'ECOLES}

\section{Résumé}

Cet article ce concentre dans l'étude développé dans l'année scolaire 2002/2003, sur les différents jeux de pouvoir et des intérêts travaillés par des acteurs dans un des charges d'administration des écoles publics: le Conseil Pédagogique. La création d'un régime d'administration des écoles engagé pour le Décret-loi no 115-A/98 a apporté des changes à la composition du conseil pédagogique. De cette façon, la plupart des acteurs de ce conseil dérive de la composition légale et des agroupements d'école, qui est venu attribuer une complexité à cette charge. À partir d'un étude de cas on prétend d'une partie analyser les différents pouvoirs dans ses membres du Conseil Pédagogique et d'autre partie réfléchir sur la forme comme les professeurs voient la participation des divers acteurs dans ce conseil. L'enquête dénonce l'existence de différents relations de pouvoir et des intérêts des professeurs de différents niveaux d'enseignement. Les décisions, les processus et les pratiques projètent surtout la prédominance des professeurs du seconde et troisième cycles devant les éducateurs d'enfance et les professeurs du premier cycle, en développant des intérêts de cycle qui peuvent fragiliser des démarches liées avec la logique démocratique.

Mots-clé

Conseil Pédagogique; Pouvoirs; Intérêts

Recebido em Novembro, 2007

Aceite para publicação em Julho, 2008

Toda a correspondência relativa a este artigo deve ser enviada para: Daniela Vilaverde e Silva, Instituto de Educação e Psicologia, Universidade do Minho, Campus de Gualtar, 4710-057 Braga, Portugal. E-mail: dsilva@iep.uminho.pt 